\title{
Does Religion Harm Science? The Case Study of the Institut Supérieur Pédagogique of Mbanza Ngungu in the Democratic Republic of Congo
}

\author{
By Joel Mbongi Kuvuna*
}

\begin{abstract}
Religion and science are an expression of human existence. However, consistent with Freud's view of religion as elusive and childish, many institutions of higher learning have omitted religion from their curriculum and consider religion as harmful to the pursuits of their departments of science. This is evident in the Democratic Republic of Congo where the secularisation of public institutions in the 1970's has resulted in the exclusion of religion as a study subject and the disappearance of theological departments in secular institutions. Secularisation seems to be misunderstood as a need to avoid any spiritual dimension, rather than in its true meaning of expressing non-religious belonging. This study explores the interface between science and religion and the apparent conflict between these disciplines at the Institut Superieur Pédagogique (ISP)/Mbanza Ngungu, one of the secular institutions of higher learning in the Democratic Republic of Congo. The findings of the study indicate that academics use science as a general concept, or an umbrella, in resisting religion or theology. On the other hand, religious believers use religion in a similar way to fight natural science. This reflects the apparent existence of a conflict between religion and science. Thereby, the fact that religion and natural science offer a different outlook on the world is negated. Although human knowledge is limited in its capacity to understand and explain the transcendental God, the theological understanding of God can fit into the scientific model. However, in the important body of knowledge represented by natural science, there is weakness. Part of this weakness lies in its ignoring of theology as a science in the field of religion. As regards the apparent conflict between religion and science, the respondents in the present study did not express perceptions of a significant incompatibility that could determine a negative relationship between science and religion. In fact, the interdependence of science and religion had been noticed and ascribed to the binary nature of human beings.
\end{abstract}

\section{Introduction}

A discussion between clergies and theologians has been opened on the possible establishment of a chaplaincy in the academic institution devoted to, inter alia, the study of the sciences and called Institut Supérieur Pédagogique (ISP)/ Mbanza-Ngungu. Similar debates are taking place in all such institutions in the Democratic Republic of Congo (DRC). One theologian voices his opinion in favour of a spiritual service in the academic institution while a representative of the clergy protests that the presence of such a service would not only be useless but even harmful in the context of scientific disciplines. Finally, the voice rejecting

*PhD Student, University of KwaZulu-Natal, South Africa. 
the establishment of a chaplaincy gets the overhand and the plan to offer services in the academic institution is suspended. The opponent argues that the academic arena must be devoted solely to scientific activities and be free from aspects of spiritual life or religion. This suggests that the debate between science and religion or faith is not just based on perceived differences between the atheism of the scientist and the spiritual views of the theist, but that Galadari is right when he states in his reflection on "Science versus religion: The debate ends," that it is also a conflict between different categories of theists. ${ }^{1}$

Based on the apparent antagonism separating science and religion, I choose as a starting point for the present paper the hypothesis that there is a lack of confidence between religion (faith) and scientific commitment. In this context the following five questions arise.

- Is it possible to separate spirituality and science?

- Can a spiritual man be separated from a scientific one?

- Is science incompatible with religion?

- Is there any science in religion or theology, and conversely is there any spirituality, religion or theology in science?

- In what way could religion harm science?

Another point to be considered at the outset of this paper is the question to which area of study science and religion do belong? The fact is that both science and theology employ scientific instruments (for example, research questionnaires) to collect data. Additionally, theology is often referred to as the Science of Religious Studies, an expression that combines the two terms, science and religion. Dealing with this topic does not imply the total negation of the tension between religion (faith) and science. One professional scientist who is passionate about both science and Christian faith qualifies some degree of tension as inevitable in the relation between science and faith. ${ }^{2}$

\section{Defining Science and Religion}

Science comes from the Latin scientia and is defined as a system of knowledge that is concerned with observation and experimentation in the physical world. ${ }^{3}$ Science has always maintained an interrelation with culture. Religion, on the other hand, is part of culture. Religion refers to a system of

1. Abdulla Galadari, "Science vs. Religion: The Debate Ends," International Journal of Science in Society 2, no. 2 (2011): 2.

2. Rebecca Bouveng and David Wilkinson, "Going beyond the How and Why of Science-Religion? Senior Christian Leaders on Science and Personal Faith," Science $\mathcal{E}$ Christian Belief 28, no. 2 (2016): 105.

3. Jacob E. Safra, "Science," in The New Encyclopaedia Britannica, ed. Jacob E. Safra (Chicago: Library of Congress Control, 2005), 504. 
thought, feeling and action shared by a group. ${ }^{4}$ Diamond defines religion as a "presumed distinction between humans and so-called animals, and a presumed uniqueness of humans in the universe."5 By contrast, he defines science as "our body of knowledge about the reality of the world as best we can understand it." Referring to the above understanding, Levin considers science and religion as two worldviews used to interpret the universe. ${ }^{6}$ Moreover, Harrison states:

"The modern terms science and religion evolved from the earlier scientia and religio, both virtues or intrinsic personal characteristics that ideally lead to particular mental dispositions: religio is a moral virtue like the inner piety, and scientia is an intellectual virtue or habit of mind."7

\section{Debate on Science and Religion}

The debate on science and religion has been influenced by, among others, three scientist-theologians, namely Ian Barbour, Arthur Peacocke and John Polkinghorne, between 1970 and the early 2000's when Peacocke and Polkinghorne were priests in England. ${ }^{8}$

Arguing for the supremacy of religion over science, Seung posits that natural science was born in the Christian world. ${ }^{9}$ This means that religion has existed for ages. Part of the history of science is the statement that the priest and the scribes were responsible for record keeping, land division, and calendar determination. They also developed written language and early mathematics. ${ }^{10}$ Talking of science and religion seems to be posing limits to the discussion. Is it not better to talk of natural, or secular, science and religion?

Considering problems of a universal nature, scholars list some of life's big questions concerning, inter alia, the beginning and the end of the universe, the compatibility of evolution and creation, the laws of nature and miracles, the nature of space and time, the problematic nature of soul, the claim of science being the only sure path to truth, the possibility that science could enable a belief

4. Barbara A. Chernow, "Religion," in Columbia Encyclopedia, ed. Barbara A. Chernow and George A. Vallasi (USA: Columbia University Press, 1993), 2300.

5. Jared Diamond, "Science \& Religion in the Rough," Humanist 76, no. 6 (2016): 13.

6. Jeff Levin, "The Territories of Science and Religion," Christian Century 133, no. 4 (2016): 46.

7. Levin, "The Territories of Science and Religion," 47.

8. Christopher Southgate, "Science and Religion in the United Kingdom: A personal view on the contemporary scene," Zygon: Journal of Religion \& Science 51, no. 2 (2016): 363.

9. Kim Seung Chul, "Śūnyatā and Kokoro: Science-religion dialogue in the Japanese context," Zygon: Journal of Religion E Science 50, no. 1 (2015): 158.

10. Henri Poincare, "Science," in The Columbia Encyclopedia, ed. Barbara A. Chernow and George A. Vallasi (USA: Columbia University Press, 1993), 2452. 
in God..$^{11}$ Science and religion are concerned with (conceptual) views of the world. This would seem to reduce both to their cognitive contents or beliefs: science to scientific theories and religion to theological views. ${ }^{12}$ Sheahen argues that "science and religion are the two essential perspectives that allow us to see the universe."13 In his view, "science takes things apart to see how they work, and religion puts things together to see what they mean." There is a partial debate argued by some scholars, raising the religion question "why?" while science asks "how?"14 On his side, Luyaluka understands that religion is one of the three epistemic components in the approach of science; thus, religion can be expressed in scientific mode. ${ }^{15}$ His understanding of the Black-African holistic epistemology affirms that the unity of science and religion can be understood by the centrality of the notion of God in understanding the world. ${ }^{16}$ Science and religion are thus understood as virtues since different points of view are needed to approach an understanding of the world and of human existence in it. ${ }^{17}$ Reflecting on natural science and Scriptures, Galileo states that both are subject to re-interpretation. He argues that the rational reasoning for God's existence does not differ from the rational explanation of the existence of gravity. Therefore, the power of reason used by atheist scientists to deduce the working of gravity is the same power used by theistic scientists to support their belief in God..$^{18}$ God can be active in the creation of life as well as in guiding life-forms persuasively towards certain goals. ${ }^{19}$

In the science-religion relation, major religious Scriptures do not condemn science. The fanaticism of followers is manifest in the generalized use of religion or science to condemn each other. ${ }^{20}$ Some scientists are convinced that science is

11. Southgate, "Science and Religion," 364.

12. Zainal Abidin Bagir, "The 'relation' between science and religion in the pluralistic landscape of today's world," Zygon: Journal of Religion \& Science 50, no. 2 (2015): 406.

13. Thomas P. Sheahen, "The Great Partnership: Science, Religion, and the Search for Meaning," National Catholic Bioethics Quarterly 16, no. 2 (2016): 355.

14. Pat Bennett, "Turning stones into bread: Developing synergistic science/ religion approaches to the world food crisis," Zygon: Journal of Religion E Science 49, no. 4 (2014): 951.

15. Kiatezua Lubanzadio Luyaluka, "Comparative Theology: Sumer, Memphis, Kongo Religion and Natural Systematic Theology," Journal of Religion and Theology 2, no. 1 (2018): 42.

16. Kiatezua Lubanzadio Luyaluka, "Religion and science conversion possibility: towards the formulation of a systematic theodicy of african traditional religion and its reinterpretation of empirical cosmology," The Journal of Pan African Studies 7, no. 7 (2014): 108.

17. Peter Harrison, "The modern invention of 'science-and-religion': What follows?" Zygon: Journal of Religion \& Science 51, no. 3 (2016): 752.

18. Galadari, "Science vs. Religion," 1

19. Jeffrey Tripp, "A New Look at the Relationship between Science and Religion, Clifford Chalmers Cain," Reviews in Religion \& Theology 23, no. 4 (2016): 455.

20. Galadari,"Science vs. Religion," 1. 
true, and religion is false. Conversely, theologians may be tempted to see religion as the truth and to declare science wrong. Many scientists unfortunately support Freud (1927), considering religion as an illusion and as childishness that ought to be overcome..$^{21}$ The interaction between faith and knowledge can be approached differently. Quoting Pantinga, Ruse argues that, "there is a superficial conflict but deep concord between science and theistic religion, and superficial concord but deep conflict between science and naturalism."22

In accordance with the above statements, people seem to try and get a grip on this problem by positing: "Science is here, and religion is here." We have now got to somehow bring the two together. And, it is important to bear in mind that both science and Christian faith are complex notions and, indeed, contested cultural spaces. ${ }^{23}$ The historian of science, John H. Brooke, claims that science and religion must each be understood in their historical and social contexts. In addition, when considering the science-religion controversy, we need to take into account that, with time, the boundaries between their domains have shifted. ${ }^{24}$ Levin, on the other hand, opines that religion and science will always be in conflict. He considers religion as a "primitive state of consciousness" which has succumbed to several centuries dominated by victories of rationalism and empirical science..$^{25}$

This research also lays on Luyaluka understanding of the Afrocentric idea to revisit the Eurocentric hegemony and epistemological view imposed on other cultures. ${ }^{26}$ The African culture on science-religion relation is positioned on epistemology, arguing four assertions which are, all reality is in God and is spiritual, any knowledge is comprised within the knowledge of God, any truth is revelation, and the matter is only a limited perception of spiritual reality.

\section{Is there any Connection between Religion and Science?}

This section discusses attempts to determine the connection between science and religion. In the words of Russels, the connection can be made apparent by looking upon the world as a pluralistic landscape. This implies being aware of the world in a more inclusive way, characterized by Russell as a worldview with an international, intercultural, interreligious, and

21. Galadari.

22. Michael Ruse, How Not to Solve the Science-Religion Conflict (USA: Oxford University Press, 2012), 620.

23. Bouveng and Wilkinson, "Going beyond," 105.

24. Bouveng and Wilkinson, 105

25. Levin, "The Territories of Science and Religion," 46.

26. Kiatezua Lubanzadio Luyaluka, "African renaissance, a solar epistemological and religious imperative for afrocentricity," The Journal of Pan African Studies 12, no. 5, (2018): 89-92. 
interdisciplinary scope. ${ }^{27}$ The present researcher agrees with Bagir that it is negative to define science by distinguishing it from religion and by showing the two as being in conflict. ${ }^{28}$ Before the nineteenth century, when science emerged as a modern discipline, there was no conflict between science and religion. Many scholars argue that the problematic categorisation of science and religion came about in a Western Christian context.

Based on a consideration of the views of various scholars, four expressions can be distilled that summarize the relation between science and religion:

1. Acceptance of diversity. Acceptance of diversity implies a tolerance of variety in a general sense, including a variety of opinions. Scholars argue that the divide characterizing the relationship of science and religion, is a construct that emerged after the eighteenth century. In order to find common ground in respect of the opposition between science and religion the acceptance of diversity is one of the procedures employed. To accept diversity is not unrelated to embracing pluralism. While we may provide justifications for the wider use of both the terms diversity and pluralism in today's world, the concept of pluralist awareness may require some further thought. ${ }^{29} \mathrm{In}$ religion, the diversity of views is a fact that has to be underlined. Each religion traditionally emphasizes different aspects of belief and religious practice and of the interplay between them. Each religion may also have its own view on scientific claims. Acceptance of diversity may be applied as long as, in respect of religious diversity and perceptions of science, basic tenets of beliefs are acknowledged.

2. Dialogue. Science, religion, and art are believed to have similar roots. ${ }^{30}$ Bouveng and Wilkinson maintain that science and religion are distinct but equal and encourage dialogue. ${ }^{31}$ In their research a number of interviewees embrace science and did not see faith and science as being in conflict. ${ }^{32}$ There is an opinion, that the problem is not located either in science or in religion, but that it is caused by fundamentalist thinking. A holistic approach to science and religion could lead to an acceptance of the different ways of each to express reality. One possibility to enable dialogue is to avoid fundamentalism on both sides of the divide between religion and science. Fundamentalism constitutes an obstacle to a true engagement with the relation between science and faith.

3. Relationship. One of the more prominent views on the divide between science and religion is concerned with the concept of relation. Drees thinks that the

27. Bagir, "The 'relation' between science and religion," 403.

28. Bagir, 408.

29. Bagir, 405.

30. Margaret Boone Rappaport and Christopher Corbally, "Matrix thinking: An adaptation at the foundation of human science, religion, and art," Zygon: Journal of Religion \& Science 50, no. 1 (2015): 85.

31. Bouveng and Wilkinson, "Going beyond," 100.

32. Bouveng and Wilkinson, 104. 
typology does not present science and religion as being in conflict. ${ }^{33}$ They surely are independent, capable of maintaining dialogue and ready for integration.

Science and religion understand the world according to their cognitive contents or beliefs. Science relies on scientific theories and religion on theological views. ${ }^{34}$ The question arises if theology is a science. If so, how can science be disconnected from religion?

The experience of the Ammatonia people in Indonesia shows that their religion is also their science, as it gives people understanding of nature and tells them how to behave and "exploit" it. Religion is a source of social-political governance as well. ${ }^{35}$ This use of religion is also found in the Christian tradition of the Old Testament in the Bible.

4. Collaboration. Fuller's study, "Into Terra Incognito," proposes that scientific and theological practitioners should find a way to collaborate in dealing with practical problems, ${ }^{36}$ while Robert Boyle describes scientific investigation as "reasonable worship." ${ }^{37}$ In the opinion of Sheahen, only belief in a transcendental God can render human existence other than tragic. ${ }^{38}$

A major concern is to bring together the reflections of scientists, philosophers and theologians with efforts that contribute to the welfare of the human community, as suggested also by Bagir. ${ }^{39}$ An Indian conception is that science and religion are not in opposition but represent forces that together could create a world in which persistent epistemological and ethical problems get resolved to the benefit of humanity. In Indian thought, rationality and spirituality are not viewed as antagonistic. ${ }^{40}$ In this context, Leidenhag reasons that God can interact with the world without breaking natural laws. ${ }^{41}$

33. Willem B. Drees, "Rich religion and science: Asian religions, Ian barbour, and much else," Zygon: Journal of Religion \& Science 48, no. 4 (2013): 853.

34. Bagir, "The 'relation' between science and religion," 406.

35. Bagir, 415.

36. Michael Fuller, "Into terra incognita: Charting beyond Peter Harrison's the territories of science and religion," Zygon: Journal of Religion \& Science 51, no. 3 (2016): 729.

37. Harrison, "The modern invention of 'science-and-religion'," 752.

38. Sheahen, "The Great Partnership," 355.

39. Bagir, "The 'relation' between science and religion," 416.

40. Anindita Niyogi Balslev, "'Science-religion Samvada' and the Indian cultural heritage," Zygon: Journal of Religion \& Science 50, no. 4 (2015): 877.

41. Mikael Leidenhag, "The relevance of emergence theory in the science-religion dialogue," Zygon: Journal of Religion \& Science 48, no. 4 (2013): 967. 


\section{Briefing of School Laity in the Democratic Republic of Congo}

Although the majority of the DRC population (85\%) are Christians, the constitution underlines the laity of the state along with freedom of religion. Maybe different contexts require that governments are secular in order to maintain neutrality when they are confronted with issues of faith (Conkle 2000). In the DRC, the secularisation of public institutions in the 1970's has led to the exclusion of theological departments and of religion as a study subject from public universities, based on the argument that the academic sphere ought to be secular. Seminaries for theology have been established independently from public institutions of teaching, although churches themselves have actually founded many universities where science is taught as it is in public universities. From the seventies onward, on the other hand, there has been no state university with a theological department in the DR Congo. The term secular has become confusing. It is as if the concept of God has in the eyes of scientists become something of an oddity. On this phenomenon, Makanzu writes "Quand Dieu te gêne" ("When God embarrasses you"), referring to the age of Enlightenment in which science has developed to a surprising degree while religion seems to have declined. ${ }^{42} \mathrm{God}$ appears to have been rejected from nature and God's knowledge has by humanity been replaced with its own wisdom.

The present research involves a case study of the Institut Supérieur Pédagogique of Mbanza Ngungu and makes clear that the opposition of science and religion is not only a Western problem. The case study was conducted in the context of Christianity. It seeks to find answers to the following questions. How do people of faith relate to science and how do scientists relate to faith? The association of Christians with science started in 1944, inspired by, inter alia, the Research Scientists' Christian Fellowship is one of the inspirations of the science-religion debate. ${ }^{43}$

\section{The Institut Supérieur Pédagogique of Mbanza Ngungu}

The ISP of Mbanza Ngungu is the first public college in the Province of Kongo Central in the Democratic Republic of Congo. It was established in 1969-1970 as a fusion of the Catholic institution Ecole Normale Moyenne de Boma and the Protestant institution Ecole Normale Moyenne de Kimpese. The ISP of Mbanza Ngungu is thus the first and oldest public institution for tertiary education in the province. It consists of more than ten departments and has in 2018 around 1,200 students. Since 1995, the institute has organised a spiritual service (chaplaincy) for students and academic staff. Catholic and Protestant

42. Mavumilusa Makanzu, Quand Dieu te gêne (When God hinders you) (Wuppertal: Editions VEM, 1986).

43. Southgate, "Science and Religion," 362. 
services are held, serving different groups of students. As the Protestant chaplaincy was better organised than the Catholic one. The Protestant chaplain was for many years granted an office in the institution. After a change of the directing team, the spiritual service was no longer allowed to take place in the area devoted to the study of science. Spirituality seemed to be perceived as a threat, by then religion seemed to harm science.

\section{Methodology of the Research}

The method of selecting participants in the research involves the use of purposive sampling. Purposive sampling is widely used in qualitative research for the identification and selection of information-rich cases and for the effective use of limited resources. The methodology is based on identifying and selecting individuals or groups that are especially knowledgeable on, or experienced in relation to, the subject of the research. ${ }^{44}$ Palinkas distinguishes many purposeful sampling designs. ${ }^{45}$ The technique is widely used but poses many challenges such as the range of variation which is often not really known at the outset of a study, and the non-existence of an insignificant number in the qualitative methods field which resists systematic sampling.

Thus, students and lecturers at the college were chosen and an invitation to participate in the research was sent to explain that interviews would be based on the interface between science and faith and focus on the question how religion might harm science in the institution.

Eighty-five persons were invited of which 72 responded and accepted. The interviewees included ISP lecturers and students from first to fifth year. 21 participants were female and 51 males. The sample consisted of 7 lecturers and 65 students of which 7 were first-year students, 33 were in second year, 5 in third year, 18 in fourth year and 2 were fifth-year students. The sample was religiously mixed and included 59 Christians, 2 Muslims, 6 people practising a traditional religion and 4 with no religion. Ten research assistants were appointed. The average length of the interviews was 30 minutes. The research was conducted in a period of approximately two weeks. The ISP of Mbanza-Ngungu was chosen for the study because it is the first public institution in the province. The aim of the research is to understand how the respondents' commitment to science relates to their faith and if they perceive religion or faith as causing harm to science.

Among the main questions were the following. How do students and lecturers relate to matters of faith? Do they consider religion or faith as a threat to their academic careers? What do they think of a spiritual service being offered on

44. Lawrence A. Palinkas et al., "Purposeful sampling for qualitative data collection and analysis in mixed method implementation research," Administration and Policy in Mental Health 42, no. 5 (2015): 533-44.

45. Palinkas et al., "Purposeful sampling." 
their campus? Is there, in the context of their studies, an interface between religion (faith) and science? The outcome of the interviews clarifies how the respondents understand the relationship between science and faith or religion.

\section{Results}

The outcome of the fieldwork is shown below.

- Is There any Incompatibility in Being a Scientist as well as a Religious or Spiritual Person?

Only $9 \%$ of the respondents said there is incompatibility. They mentioned some contradictory theories of science and of religion such as evolutionism and creationism. Respondents who saw science and religion as compatible referred to the supremacy of God and looked upon spirituality as the mother of natural science. Religion does not oppose scientific knowledge which helps faith.

Looking at the position of church leaders in the United Kingdom in relation to science, it is found that a majority of senior leaders expresses the wish for a "science-faith relation," defined by compatibility, mutuality and/or complementarity. ${ }^{46}$ For many scientists, the discovery of God in a scientific context is a way of worshipping and praising God.

- Can an Academic Sphere also Be Spiritual?

Most respondents were of the opinion that nothing could embarrass them and make them refrain from expressing their belief on campus. Those who were of the view that a scientific milieu can also be religious argued that the supremacy of God dominates above all and hence freedom of expression and religion are paramount. They stated that spirituality makes a good scientist and the supernatural status of the human being implies that humanity must not be considered as only material but also spiritual in nature.

The opponents of the idea that the scientific sphere has also spiritual aspects, said that, while encountering in their study environment a diversity of scientific and spiritual considerations, they had found that each needs to be dealt with on its own merits, in its own time. Many respondents seemed to be confused about the difference between church and spirituality. They also confused church attendance with spirituality, emphasizing that there is a time for everything. In my opinion, there is no need for church services to interfere with times set apart for lectures. Spirituality is part of the human being. The rejectors also posited that in science there is evidence of facts whereas religion is based on faith. Finally, they stated that an encounter between science and religion might result in faith becoming weakened.

46. Bouveng and Wilkinson, "Going beyond," 114. 
In interviews with church leaders in the United Kingdom, a majority of senior leaders stipulated that "no scientific discovery could shake my faith," even though they acknowledged the existence of tensions between faith and Scriptures, science and reason, as manifested in numerous questions in connection to, for example, the miracles, the future of the universe, evolution and creation. ${ }^{47}$ The researcher came to the conclusion that the academic sphere has to be considered multisectoral, as it centers on the nature of the human being.

- Can Scientists in their Scientific Explorations Be in Need of Religion, and Vice Versa?

The majority of respondents was in agreement about the interdependence of science and religion because, it was argued, every human being is endowed with an openness to the supernatural, or with a religious inclination. The universe is interconnected. Our ancestors respected the signs of time and space and the Bible suggests adding science to faith. Religion follows some rules and is thus also a science. Often biblical statements are confirmed by science. Science without morality destroys the soul. However, some respondents placed religion above science. Others expressed the opinion that religion needs science, or, to the contrary, that science needs religion but that there is no reciprocal need.

- Can Science and Faith Be Equal Partners or Not?

The interviewees were divided in this respect. Some stated that science and religion can match for three reasons.

1. The first one, God is the source of intelligence while being omnipotent, omniscient, and omnipresent.

2. Secondly, science and religion operate in different fields. Each needs to respect the principles of the other as they deal in different ways with human beings. As in the words of Harrison, science and religion are seen as different lenses used for interpreting the universe. ${ }^{48}$

3. And lastly, the practice of faith also requires knowledge. While the study of science is relatively new, belief has existed since times immemorial. ${ }^{49}$ The Bible refers to aspects of biology, geography, and history. Science can deepen faith which, in turn, enlightens science when working for faith, even while using opposite methods.

Those interviewees who thought that religion and science cannot be equal partners, advocated for a parallel position of the two. In their view, science relies on logic, criticism and verifiability, while religion is governed by faith and feeling. In other words, science is directed by the evidence of fact whereas religion by

47. Bouveng and Wilkinson, 113.

48. Levin, "The Territories of Science and Religion," 48.

49. Chul, "Śūnyatā and Kokoro," 158. 
contrast is dominated by faith and the supernatural. This view can obviously be criticised. It seems that faith has no space for rationality but, in fact, when people engage in a discussion of faith, they base their arguments on rationality.

Karl Popper's perception of rationality is fascinating. He understands rationality as acting so as to introduce a change into one's world or in one's view of the world. To refrain from acting is to leave one's world or one's view of the world unchanged. In this way, even faith becomes a rational act. In Christine Korsgaard's thought, to act for a reason necessitates that one starts by determining what one's reasons are. As she puts it, not every human impulse is a reason to believe, nor is every desire a reason to act. ${ }^{50}$

- The Common Points Between Science and Religion Considered.

The respondents were almost in total agreement on the key points that science and religion have in common. Four points were identified as the following.

1. Firstly, the search for truth and knowledge. Truth is one of the main themes of Jesus in the Christian tradition. Pilate asked Jesus what truth is (John 18.38). The human being wants to know, to discover. Religious people want to know and discover truth by faith. Scientifically inclined people want to know and discover by way of experimenting.

2. Secondly, the transcendental God. God is not experienced through and explained by human knowledge. Faith in God does not depend on human experience. The coming to God can be explained neither by science nor by religion. God, being supernatural, is beyond all-natural expression. Talking about the transcendental God, Sheahen states: "Only something or someone outside the universe can give meaning to the universe. Only belief in a transcendental God can render human existence other than tragic."51

3. Thirdly, the human being. Humanity is at the centre of the cosmos. The human being should not be used as an object of experimentation, because dignity has been bestowed on him or her. God put a sacred seed of worth in human beings that must be protected. The dignity of human and other beings must be protected. Otherwise, the result would be deeply offensive to God. The Psalms describe human dignity as follows.

What is Man that you are Mindful of him, and the Son of Man that you Visit him? For you have made him a little lower than the angels, and you have crowned him with glory and honour. You have made him to have dominion over the works of your hands; you have put all things under his feet (Psalms 8: 4-6).

4. And fourthly, the law and rules that convey the scientific character. There are some rules in every searching for God, and in any experimental, scientific step.

50. Menachem Fisch, "Science, Religion, and Rationality: A Neo-Hegelian Approach," Toronto Journal of Theology 29, no. 2 (2013): 320.

51. Sheahen, "The Great Partnership," 355. 
- The Importance of the Spiritual Structure in an Academic Environment.

The majority (91.7\%) of respondents appreciated the importance of a spiritual structure in the academic sphere which in their view would empower scientific values and good morality. To exclude the spiritual dimension in human existence is to miss a part of human reality. We do not only need to feed the mind, but also the heart. Science without consciousness ruins the soul. In fact, the ISP (Institut Supérieur Pédagogique) of Mbanza Ngungu should consider spiritual life or engagement as part of nurturing the humanity of its students and staff.

- How Can a Scientist be Involved in Religious Matters?

This question is not only concerned with atheism and theism. The involvement of scientists in religious matters depends on how one conceives of involvement. The respondents in the present study suggested that the scientist who is also religiously involved, needs to have a clear vision of what science offers and what religion represents. A profound understanding of the two approaches to life would motivate one to adopt the right attitude towards handling apparent confusion in respect of science and religion by separating contradicting theories on religion and by explaining natural facts such as rain or lightning. The religious scientist must demonstrate, in his or her behaviour and in the use of natural science, respect for human dignity.

\section{Conclusion}

This paper started by mentioning an ongoing debate between clergies on religion and science in academic institutions. The research was aimed at determining ways in which religion could be perceived as being harmful to science. In discussions on the relationship between religion and science, many scholars argue that religion and science represent two different views of the world.

The connection between the two disciplines can be seen by considering the world as an inclusive, pluralistic landscape that encompasses intercultural, interreligious, and interdisciplinary relationships. To deal with the reality, four qualities have been emphasized, namely acceptance of diversity, dialogue, relationship and collaboration. The research that was conducted at the Institut Supérieur Pédagogique of Mbanza Ngungu, reveals that respondents did not see religion as having harmful effects on science. Some people apparently follow Freud's view and consider religion as elusive and childish. If religion would have caused any harm at the ISP, it would have been a result of scientific fanaticism that uses science as an umbrella for an overall condemnation of religion.

Far from closing the debate, the present reflection on science and religion 
describes both disciplines as forms of science, characterized by their own modus operandi which they apply to increase their understanding of reality. Similarity is no necessary condition for collaboration as differences are a part of diversity.

The present researcher, finally, supports the concepts of natural science and religious science. The question how to connect the two may find the beginning of an answer in the following statement.

"Even a detailed account of the history of science cannot be complete, for scientific activity is not isolated but takes place within a larger matrix that also includes, for example political and social events, development in the arts, philosophy and religion, and forces within the life of the individual scientist. In other words, science is a human activity and is affected by all that affects human being in any way." 52

Science and religion should not be antagonistic disciplines but could represent forces to create a world in which persistent problems get resolved for the benefit of humanity. Furthermore, in the context introduced by Kiatezua L. Luyaluka, it is natural for African to perceive no conflict between religion and science.

\section{Bibliography}

Bagir, Zainal Abidin. "The 'relation' between science and religion in the pluralistic landscape of today's world." Zygon: Journal of Religion E Science 50, no. 2 (2015): 403-17.

Balslev, Anindita Niyogi. "'Science-religion Samvada' and the Indian cultural heritage." Zygon: Journal of Religion \& Science 50, no. 4 (2015): 877-92.

Bennett, Pat. "Turning stones into bread: Developing synergistic science/ religion approaches to the world food crisis." Zygon: Journal of Religion \& Science 49, no. 4 (2014): 949-57.

Bouveng, Rebecca, and David Wilkinson. "Going beyond the How and Why of Science-Religion? Senior Christian Leaders on Science and Personal Faith." Science \& Christian Belief 28, no. 2 (2016): 100-16.

Chernow, Barbara A. "Religion." In Columbia Encyclopedia, edited by Barbara A. Chernow and George A. Vallasi. USA: Columbia University Press, 1993.

Chul, Kim Seung. "Śūnyatā and Kokoro: Science-religion dialogue in the Japanese context." Zygon: Journal of Religion \& Science 50, no. 1 (2015): 155-71.

Diamond, Jared. "Science \& Religion in the Rough." Humanist 76, no. 6 (2016): 12-6.

52. Poincare, "Science," 2454. 
Drees, Willem B. "Rich religion and science: Asian religions, Ian barbour, and much else." Zygon: Journal of Religion E Science 48, no. 4 (2013): 853-58.

Fisch, Menachem. "Science, Religion, and Rationality: A Neo-Hegelian Approach." Toronto Journal of Theology 29, no. 2 (2013): 319-36.

Fuller, Michael. "Into terra incognita: Charting beyond Peter Harrison's the territories of science and religion." Zygon: Journal of Religion E Science 51, no. 3 (2016): 729-41.

Galadari, Abdulla. "Science vs. Religion: The Debate Ends." International Journal of Science in Society 2, no. 2 (2011): 1-9.

Harrison, Peter. "The modern invention of 'science-and-religion': What follows?" Zygon: Journal of Religion \& Science 51, no. 3 (2016): 742-57.

Leidenhag, Mikael. "The relevance of emergence theory in the science-religion dialogue." Zygon: Journal of Religion E Science 48, no. 4 (2013): 966-83.

Levin, Jeff. "The Territories of Science and Religion." Christian Century 133, no. 4 (2016): 46-50.

Luyaluka, Kiatezua Lubanzadio. "Comparative Theology: Sumer, Memphis, Kongo Religion and Natural Systematic Theology." Journal of Religion and Theology 2, no. 1 (2018): 31-45.

Luyaluka, Kiatezua Lubanzadio. "Religion and science conversion possibility: towards the formulation of a systematic theodicy of african traditional religion and its reinterpretation of empirical cosmology." The Journal of Pan African Studies 7, no. 7 (2014): 108-39.

Luyaluka, Kiatezua Lubanzadio. "African renaissance, a solar epistemological and religious imperative for afrocentricity." The Journal of Pan African Studies 12, no. 5 (2018), 89-92.

Makanzu, Mavumilusa. Quand Dieu te gêne (When God hinders you). Wuppertal: Editions VEM, 1986.

Palinkas, Lawrence A., Sarah M. Horwitz, Carla A. Green, Jennifer P. Wisdom, Naihua Duan, Kimberly Hoagwood. "Purposeful sampling for qualitative data collection and analysis in mixed method implementation research." Administration and Policy in Mental Health 42, no. 5 (2015): 533-44.

Poincare, Henri. "Science." In The Columbia Encyclopedia, edited by Barbara A. Chernow and George A. Vallasi. USA: Columbia University Press, 1993.

Rappaport, Margaret Boone, and Christopher Corbally. "Matrix thinking: An adaptation at the foundation of human science, religion, and art." Zygon: Journal of Religion \& Science 50, no. 1 (2015): 84-112.

Ruse, Michael. How Not to Solve the Science-Religion Conflict. USA: Oxford University Press, 2012.

Safra, Jacob E. "Science." In The New Encyclopaedia Britannica, edited by Jacob E. Safra. Chicago: Library of Congress Control, 2005.

Southgate, Christopher. "Science and Religion in the United Kingdom: A personal view on the contemporary scene." Zygon: Journal of Religion $\mathcal{E}$ Science 51, no. 2 (2016): 361-86. 
Sheahen, Thomas P. "The Great Partnership: Science, Religion, and the Search for Meaning." National Catholic Bioethics Quarterly 16, no. 2 (2016): 355-58.

Tripp, Jeffrey. "A New Look at the Relationship between Science and Religion, Clifford Chalmers Cain." Reviews in Religion \& Theology 23, no. 4 (2016): 454-57. 